\title{
A MODERNIST APPROACH TO THE
}

\section{POSTMODERN PERIOD IN TURKISH AND}

\section{WESTERN PAINTING}

\author{
Oğuz YURTTADUR ${ }^{1}$
}

\begin{abstract}
Postmodern thought allows us to continuously question modernism. Postmodernism is being prodigiously fed by all the resources of globalism and is also perceived as being in opposition to itself. Art in the present day is both a form of production, making use of the advanced technology developed in the past forty or fifty years. It includes many factions coming to terms with the perception of the universe created by modernism. This account-squaring investigates universalism, uniqueness, originality and belonging issues in modernism and establishes the micro-discourses and policies along with a pluralist perception of the world that internalize the differences between the species, which are all postponed by the center. As it did in the world at large, the postmodern approach has made it possible to re-interrogate many issues in Turkish painting, from the multidimensional use of materials to opinions, values and judgments accepted as taboos. Postmodern thought brought new and different conceptual and institutional approaches to Turkish painting and Turkish painters. Accordingly, Turkish artists began to spend more time on thought, merged rapidly with foreign art and transcended the borders of painting, place and materials in the postmodern period.
\end{abstract}

Keywords: postmodern painting, modern art, Turkish painting

Yurttadur, O. "A Modernist Approach to The Postmodern Period in Turkish and Western Painting”. idil 4.16 (2015): 125-132.

Yurttadur, O. (2015). A Modernist Approach to The Postmodern Period in Turkish and Western Painting. idil, 4 (16), s.125-132.

Yrd. Doç. Dr., Selçuk Üniversitesi, Güzel Sanatlar Fakültesi, Heykel Bölümü, Konya, oyurttadur(at)hotmail.com 


\title{
TÜRK VE BATI RESMINDE POSTMODERN ANLAYIŞ SÜRECINE MODERNIST BIR BAKIŞ
}

\begin{abstract}
ÖZET
Postmodern, günümüzde küreselleşmenin var olan tüm kaynaklarından beslenerek hızla ilerlerken, temelde sadece karşı durduğu bir zaman dilimiymiş gibi algılanan modernin de unutulmadan sürekli sorgulanmasına kaynaklık etmektedir. Günümüz sanatı, bir yandan üretim biçimi olarak son kırk-elli yıla yayılan ileri düzeyli teknolojik yeniliklerden payını alırken, öte yandan da modernin ortaya koyduğu evren algılamasıyla hesaplaşan bir dizi kırılmayı bünyesinde barındırmaktadır. $\mathrm{Bu}$ hesaplaşma, modernin evrensellik, biriciklik, orjinallik ve aidiyet meselelerini sorgularken, yerine merkezin ötelediği mikro söylemleri ve politikaları, türler arasındaki ayrımların duruma uğratıldığı plüralist bir dünya algısını yerleştirmiştir. Postmodern anlayış ile tüm dünyada olduğu gibi Türk Resim Sanatı'nda da çok yönlü malzeme kullanımından, tabu olmuş görüş, değer ve yargılara kadar yeniden sorgulama mümkün olmuştur. Postmodern anlayış Türk Resim Sanatı ve sanatçısı için yeni ve farklı kavramsal/kurumsal yaklaşımlar doğurmuştur. Bu bağlamda fikir üzerinde daha fazla zaman harcamaya başlayan Türk sanatçısı dünya sanatı ile hızla kaynamış ve postmodern sürçte resim, mekân ve malzemenin dışına çıkmıştır.
\end{abstract}

Anahtar Kelimeler: postmodern resim, modern sanat, Türk resim sanatı 


\section{Introduction}

In order to understand post-modernism, one must first understand what one means with modernism. The word 'modern', which has a quite prevalent use today, originally means 'just now'in Latin. According to Habermas, the idea of modernity as a process has always existed, therefore its origin of existence must not be restricted to Renaissance and/or Enlightenment. On the other hand, the phrase 'postmodern art' is used in contemporary art in order to refer to an eclectic inclination (Y1lmaz, 2005:12-13). Two distinct understandings of post-modernity can be mentioned. In the first account, post-modernity is admitted as a criticism raised against modernity. In the second, on the other hand, it is considered as a specific state of modernity that derives from modernity and defined along these lines. In truth, if a broader perspective is adopted and data from different fields is taken into consideration, it is possible to say that there are evidence and indications to support either approach (Kahraman, 2004:9). Advancing swiftly by utilizing all the existing resources of globalization today, and making modernity a constant subject of scrutiny to itself, in fact post-modernism has promoted the currency of modernity which is normally considered as just the opposite of post-modernism. Thus it has made certain influences in art, culture and politics. Even though modernism, in the words of Paul Klee, has always devoted itself to discovering 'the essence of the accident,' it had to do it within a domain that, due to the constant change of its moments, seems to 'deny the rational experience of yesterday' (Harvey, 2003:25). That is, the fundamental idea on which modernism depends is that literature, politics, present cultural structure, and as well as traditional arts, should be left aside and a new culture should be invented. Looked in this way, it can be said that, by taking the prefix 'post,' modernism its own has laid the foundation of making itself a subject of scrutiny.

With post-modernism, distinctions and hierarchy between crafts/tradition and thought and high art begins to disappear. The hierarchy in plastic arts in terms of the antique and the present can be ignored. Thus the antique and the present can stand side by side. With post-modernism while instead of the terms 'painter' and 'sculptor,'the term 'artist' has come to be prevalent, the term 'artifact' leaves its place to the terms 'work' and 'study' (Akay, 2005: 116-117). According to Şahiner, today's art, while on the one hand, as a certain mode of production, takes its share from the hi-tech innovations of the last forty-fifty years, on the other hand, in reckoning directly with the modernist conception of the world, harbors within itself a number of break-offs from modernism. This reckoning puts the issues of "universality," "uniqueness" and "belonging," which are predominant concepts of modernism, under question, and replaces them with (i) micro discourses and politics 
that are decentralized by the system, (ii) a pluralist conception of the world that destroys the distinctions between species, and (iii) a theoretical infrastructure that proclaims the death of the author/artist (Şahiner, 2008:11). In fulfilling the ideals of Enlightenment, modernism takes as its motto "I feel therefore I am" instead of that of Descartes" "I think therefore I am," and leaves the rational and means-oriented strategy, taking consciously quite a radical turn towards an aesthetic strategy. The emergence of aesthetics as a separate domain of knowledge falls explicitly in the eighteenth century (Harvey, 2003:33). The need for understanding the prosperous diversity of cultural products, which are produced in very different social conditions that have been affected by the increase in cultural contact brought about by the enhancement of commercial relations through time, has led the artist to look for new quests. At this point, the concept of singularity has its source in the subjective nature of experiences. The radical nature of the experience causes in the perceiver certain judgments which are seemingly both universal and necessary. This, among others, is definitely what the aesthetic experience knows; therefore, it can be named to a certain degree as a special sort of "knowledge" that is provided by art works. However, a work of art does more than that. Each experience is singular to each audience, and, at the same time, each experience is singular to each work of art (Bolla, 2006:139). While the avant-garde artist, preventing its work from turning into a commodity, wants to demolish art as an institution and to unite it with society, the post-modern artist unites art and society by turning art totally into a commodity (Yıldızoğlu, 2005:156).

Modern art emerges out of its problematical relationship with the reality of knowledge that exists from the beginning of art. One of the most important facts concerning this relationship is the problem of mimesis. The art work, which at the outset emerges out of being directed at nature and is manifested through the direct reflection of nature onto canvas, with the rise of modernity to an higher level of consciousness, begins to drift apart from nature and to spring out of itself. Not being directed towards natural reality anymore and not being constituted through the mediation of it, the art work, which is now both the subject and object of itself, comes to have a new, transcendental dimension (Kahraman, 2005:208). Looked from this perspective, eclectic structures and ready-made objects that are encountered in post-modern era are an indicator of the resolution in art of a great deal of boundaries. Now, the artist is able to enter into interdisciplinary relationships as she/he wishes, because numerous subtopics whose subject matters consist in the new concepts and analysis, such as micro-politics, interdisciplinary studies, multilayeredness, subculture critique, which are brought into currency by post-modern theory, are part of the problems of the age in which the artist lives. 
Postmodernism is a sort of aesthetics of quote and compilation. Besides, it seems that a number of new movements and trends, such as Neo-impressionism or Neo-cubism, which are qualified by the prefix 'neo' are reckoned under the headline of 'post-modernism'. Synthetic Cubism, Dadaism and Surrealism of pre-1940s; pop art, performance arts, body art and movie art of post-1950s definitely cannot be characterized as fitting into the typology of modernism. As it appears, the concept of 'post-modernism', despite some negative connotations it bears, is used as an umbrella term under which a series of movements and trends lie. Along these lines, the term Collage has come to be used as an art term since Braque and Picasso. What is more, in virtue of these people this term has come to mean not only a painting technique but also a type of painting. Picasso's Still Life with Chair Caning consists of objects that are not produced for artistic purposes. That this work has a heterogeneous character is that in which the post-modern nature of the work consists. The same is the case with the three dimensional assemblages of Picasso. The pieces of scrap that Picasso used in his sculptures were originally produced for non-artistic purposes. However, Picasso took those pieces out of their original context and placed them in a new, artistic one. For example, the head of Baboon and Young was originally a toy car, while Guitar, a sculpture of his, is nothing but obviously a combination of sheet metal and wire. The pieces used in these works obviously serve as parts of a whole, a finished sculpture, yet they do not stop manifesting their original identity they have independently of the whole. The application of montage technology to art that in first hand belonged to the world of machines gives rise to the emergence of heterogeneous works of art. In short, the concepts assemblage and montage are characteristic concepts of post-modernism as much as they are of modernism (Y1lmaz, 2005:344-345).

No doubt, at this stage arises the question of what kind of relationship there is between painting and post-modernism. Especially when one thinks the developments in Turkey, finding out the nature of the link becomes more important because, besides that which is produced anew, the idea too, which gives an existence to the product on the platform, has taken its share from 'it has been done before'. If the heterogeneous character that is specified by post-modern painting already exists in the nature and development process of modern painting, then to search for postmodernism merely by the agglomeration of styles is quite inconsistent. (Erguven, 2002:183) 


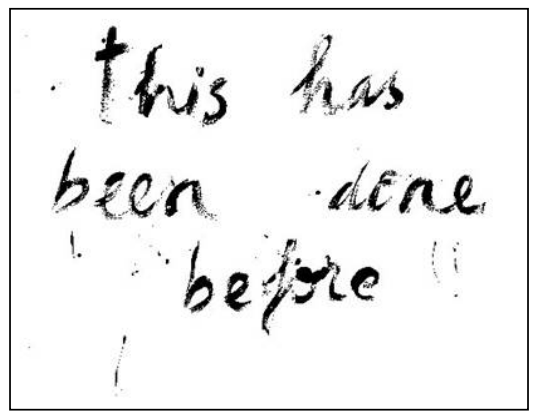

Bedri Baykam, This Has Been Done Before, 1987.

Canan Baykal, in her work called Ellams Duplicator Patent No. 230345, which appears in her exhibition 'A Section from 4th Turkish Avantgarde Art', uses a 1924 model English made xerox machine as a ready made object. Believing in the mediatedness of life, the artist is interested in the spontaneity of primitive art and the immediateness of ready made object. Wishing her works to possess as much an artless function as life and nature could have, Baykal always observes her surroundings attentively and never remains indifferent to the events taking place in her society. Paying no mind to the negative criticisms of some art circles, she uses the ready made object as an indicator of social behavior. Perceiving objects around her as tools to be made use of as a form of social manifestation, the artist draws upon signs, codes, xerox copies and photographs so as to make manifest the cause of the existence of the object (Atakal, 2008:115).

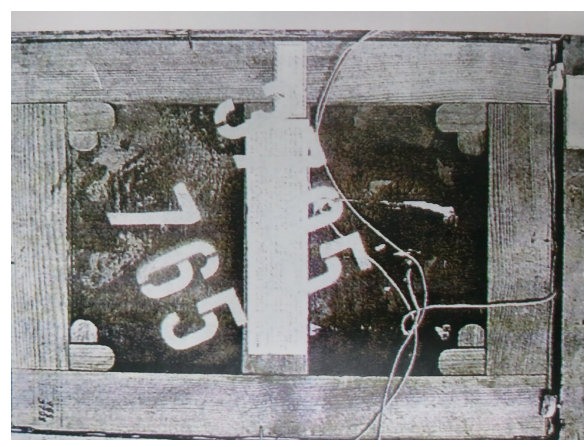

Canan Beykal, Ellams Duplicator Patent No. 230345, 1987. 
The Time of Emptiness made by Serhat Kiraz for the 45th Venice Biennial in 1993 is composed of painted glass panels on which are covered tarot card images that symbolize the universe. The artist orders the panels in a spiral manner and provides them with an illumination from the bottom by making use of small bulbs. Functioning in a way as reflecting mirrors and capturing the reflections of the audience, these panels introduce into the work the 3rd dimensionality. With this work, Kiraz aims to show the need in people to believe in a power other then themselves regardless of time differences. For example, during a war time, people, while questioning the power of the acknowledged religions, notice that they actually live in an emptiness. Thus something that seems attractive at first sight prompts the individual to come to see that the universe has no beginning, end, limits or edges. (Atakan, 2008:129)

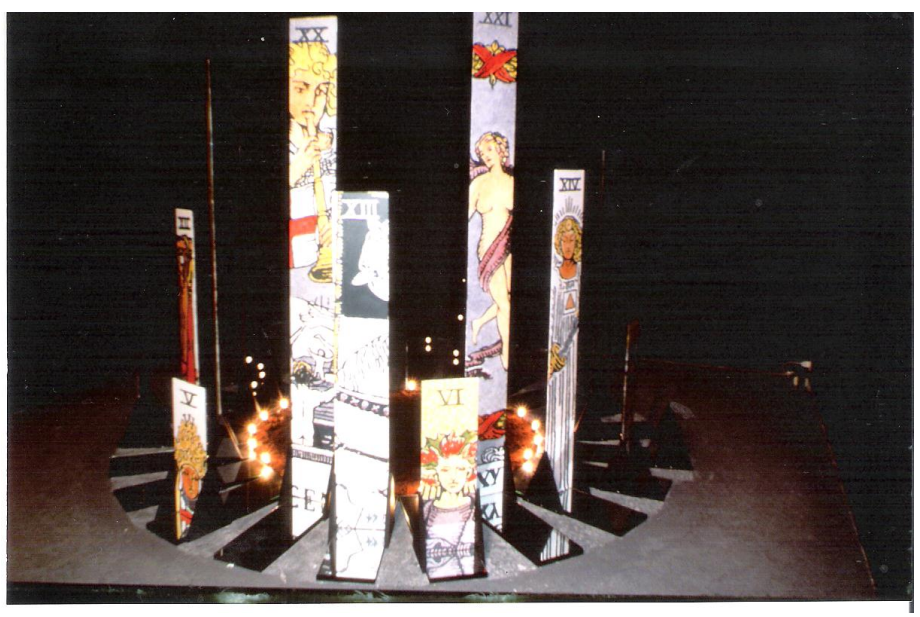

Serhat Kiraz, Boşluk Zamanı, 1993.

\section{Conclusion}

As it is the case in the whole world, post-modernism, by allowing the multifaceted use of the material, made possible in Turkish painting the questioning of widely held opinions/values which came to be taboos. It provided both Turkish painting and the Turkish artist with different conceptual and theoretical approaches. In search of new aesthetic possibilities, the post-modern subjected all the classical judgments to questioning, and in this way it created new intellectual spaces for itself 
within the history. Turkish painting has never stepped outside the domain of these new problematics, and always within this domain interdisciplinary productions have been made. The fact that post-modernism encourages and makes valuable that which is different has allowed the Turkish artist to make analysis of interdisciplinary practices. The artist has begun to spend much more time on the idea. As the Turkish artist, who has been fusing with the world art a speedily pace, sees it, in postmodernism painting went well beyond the limits of space and material.

\section{Bibliography}

Akay, Ali. Postmodernism. İstanbul: L ve M Yayınları, 2005.

Atakan, Nancy. Alternative Quests in Art. İzmir: Karakalem Kitapevi, 2008.

Bolla, Peter. Art and Esthetics. İstanbul: Ayrıntı Yayınları, 2006.

Ergüven, Mehmet. Towards Comment. İstanbul: Yapı Kredi Kültür Sanat Yayıncılık, 2002.

Harvey, David. State of Postmodernism. İstanbul: Metis Yayınları, 2003.

Kahraman, Hasan Bülent. Turkey between Postmodernity and Modernity. İstanbul: Everest Yayınları, 2004.

Kahraman, Hasan Bülent. Artistic Realities, Facts and Beyonds. İstanbul: Agora Kitaplığı, 2005.

Şahiner, Rifat. Postmodern Breakdowns in Art or Deconstruction of Modern. İstanbul: Yeni İnsan Yayınevi Sanat Serisi, 2008.

Yıldızoğlu, Ergin. Moral of Dog; On Esthetics, Autonomy and Politics. İstanbul: Gri Yayınevi, 2005.

Yılmaz, Mehmet. Art from Modernism to Post-modernism. Ankara: Ütopya Yayınları, 2005. 